\title{
Conceptualisation of a Graduate Employability Framework from a Malaysian Perspective
}

\author{
Dr. Seetha Nesaratnam (corresponding author) \\ Trainer, Dale Carnegie Training Malaysia \\ Phileo Damansara II, 15 Jalan 16/11, 46350 Petaling Jaya, Selangor \\ E-mail: seetha@dalecarnegie.com.my
}

\author{
Shivaani Prabha Karan \\ Heriot-Watt University \\ School of Business, Boundary Rd N, Edinburgh EH14 4AS, UK \\ E-mail: shivaanihunt@gmail.com
}

Foo Yi Von

General Manager and Trainer, Dale Carnegie Training Malaysia

Phileo Damansara II, 15 Jalan 16/11, 46350 Petaling Jaya, Selangor

E-mail: yivonfoo@dalecarnegie.com.my

Received: Aug. 21, 2018 Accepted: Sep. 24, 2018 Online published: Oct. 23, 2018

doi:10.5296/ijhrs.v8i4.13813 URL: https://doi.org/10.5296/ijhrs.v8i4.13813

\begin{abstract}
Skills shortage among graduates is a serious constraint in Malaysia and according to Bank Negara Malaysia, graduate employability in Malaysia is a rising concern as graduates represent 23 per cent of total youth unemployment. As Malaysia aggressively sets course towards becoming a high-income economy, the need for skilled manpower is said to be expanding across key industries. To ensure a productive workforce, the country must have a high-quality flow of talent supply to fill these jobs. Hence, the study investigates the antecedents of graduate employability in Malaysia by researching a key stakeholder group, which is the employer.
\end{abstract}


Using a qualitative research methodology, ten employers were interviewed using in-depth interviews to explore and enrich the graduate employability framework. The qualitative phase inducted the 'graduate training' construct and its sub-constructs of 'internship', 'mentoring' and 'talent management', as perceived by the employers, which were added as enrichment to the graduate employability framework. It also affirmed and authenticated the 'soft skills' construct drawn from literature. By incorporating the findings from the qualitative phase, an enriched framework eventuated. This enriched framework brings these previously omitted dimensions to the forefront.

Keywords: dimensions, employers, framework, graduate employability, work-readiness

\section{Introduction}

As the business world moves towards becoming increasingly competitive, along in its trajectory, the demand for right-skilled graduates is also rising in tandem. University graduates around the world are facing the challenge of a precipitous trend of unemployment (Rae, 2008; Thern, et.al, 2017). Samkin and Stainbank (2016) raised the argument that, the curriculum of Higher Education Institutions (HEIs) failed to prepare work-ready graduates to meet employers' expectation in terms of skills, attributes and professional qualities. This thrusts forward the notion that graduate employability requires graduates to be equipped with the necessary attributes and skills aligned to the requirements of the labor market.

The Malaysian government through its economic planning unit in 2015, laid out the plan for the country to achieve high-income country status by the year 2020 (Economic Planning Unit, 2015). As the country's knowledge driven economy is on a steady growth path, inevitably it is predicted that there will be ample employment opportunities for high skilled workers in the foreseeable future (TalentCorp Malaysia, 2016). As the country spearheads itself towards achieving a high-income economy status, employment and the need for high skilled workers is also growing across critical economic sectors. This acute need for a skilled and productive workforce requires the country to look into ensuring a high-skilled talent supply. A talented and high skilled workforce is a necessary factor in driving the economy and will help avoid a growing skills imbalance. This is undoubtedly a clarion call for the country to ensure that there is adequate supply of high quality professional labor in preparation for the upcoming opportunities (Hanapi and Nordin, 2014). According to Bank Negara Malaysia (2017) in its Policy Outlook report, graduate employability in Malaysia is a rising concern as graduates represent 23 per cent of total youth unemployment in the country. The report adds that the key reason for this alarming state is because graduates are not equipped with the necessary skills. The report further reiterates that Malaysian firms face challenges in sourcing talent because many Malaysian graduates do not possess the type of skills demanded by employers. A study by Talent Corporation Malaysia (TalentCorp) and the Institute of Labour Market Information and Analysis (ILMIA) found that the top three difficulties companies face in filling up critical occupations are (1) expected standards that are not met by the applicants; (2) applicants do not have critical employability skills such as communication and interpersonal skills; and (3) applicants have the necessary academic qualifications, but have unrealistic expectations for salary and rewards (TalentCorp Malaysia, 2016). This problem is further 
intensified by the lack of collaboration between the HEIs and the industries (Govindaraju and Wong, 2011; Rateau, Kaufman and Cletzer, 2015). Hanapi and Nordin, 2014; Rahmat, Ayub and Buntat, (2016) argue that Malaysia faces an acute graduate unemployment problem not because of limited employment opportunities, but mainly because of graduates who are not work-ready. Graduate employability research in Malaysia is mainly tuned to identifying employability skills rather than a holistic study that explores other causal factors (Seetha, 2014; Tan et al., 2017). According to Nesaratnam and Gayen (2018), the concept of employability in literature has thus far been ambiguous and contentious without a single definitive description. Whilst conceding the graduates vested interest in this concept Nesaratnam and Gayen, reiterate that the employers' perspective on employability is primarily important and needs further investigation.

The paper makes two contributions. First, by focusing on the employers' perspective, other dimensions to graduate employability are revealed hence addressing the current anomaly of an escalating unemployment problem of Malaysian graduates. Second, as there is very little research on the role played by employers in building employability (De Vos, De Hauw and Van De Haijden, 2011), the findings present how graduate training supports the underlying principles of employability which expands the current body of knowledge on graduate employability.

The paper begins with an appraisal of relevant literature. The results of ten in-depth interviews with employers from a cross section of industries are presented to show other dimensions of graduate employability from the employers' perspective. The theoretical and practical implications of these findings are then discussed to demonstrate how key stakeholders such as the employers, the graduates, the government and the HEIs can benefit from the enriched graduate employability framework.

\section{Literature Review}

\subsection{Defining Graduate Employability}

Govender and Wait, (2017) argue that the volume of research and debate through varied stakeholder perspectives on employability over the last five decades still cannot offer a clear definition on the subject matter. Govender and Wait, (2017) present employability as the ability of graduates to start work as effective professional employees from first day of employment. The need for clarity of this concept will be incredibly helpful to graduates to enable them to chart their future career and know what is expected of them. Copps and Plimmer (2013); Govender and Wait, (2017), argue that employable graduates are easily distinguishable from the rest because they have work needed skills, distinct attributes and characteristics. They identified them as; lifelong learning, professional development, ability to apply and integrate theory and practice, decision-making and collaboration. Morrison (2013) introduced the concept of absolute employability in his study and explains absolute employability as graduates who have the necessary skills, knowledge and commitment to do the job. Nilsson (2010) in his study defines employability as the ability of individuals to find employment and remain employed. Dacre Pool and Sewell (2007); Dacre Pool, Qualter and Sewell (2010) define employability as, having a set of skills, knowledge, understanding and 
personal attributes that make a person more likely to choose and secure occupations in which they can be satisfied and successful. They go on to add that the perspective of employability can be explained as the graduate's propensity for exhibiting skills and attributes required by the employers to be a fully functioning employee. Hillage and Pollard (1998), describe employability as person's ability to gain employment, sustain employment, shift to other functions within the same firm, gain new employment if needed and function in a work capacity that brings fulfillment and satisfaction. According to Minocha Hristova and Reynolds (2017) employability is the graduate's ability to use their specific skills set in a way that is expected by the employer for the benefit of the organization. Harvey (2001) rejects the notion that, employability is limited to the understanding of a set of skills needed to gain employment and refines the concept to a process of learning and acquiring new experiences and attributes.

Due to the absence of a single definitive description of employability, a closer inspection of employer's expectation of graduates in terms of employability will take place in the section below.

\subsection{Employers' Expectation}

Despite the volume of graduates being produced and the increased emphasis on vocationalism in tertiary education in developing employability skills among graduates, a recurring discontentment voiced by the business community is the HEIs' inability to produce graduates who meet employers' expectations (Connor and Shaw, 2008). The European Commission, noted that graduates who lack employability skills come at a great cost to their employers as well as themselves. The study aimed to demonstrate that cost of underperformance of graduates outweighs the possible benefits of above average performance. Graduates who belong to the top 25 per cent of their group have ten to 15 per cent higher productivity compared to the average graduate. But the graduates who belong to the bottom 25 per cent of their group have on average a 20 to 30 per cent lower productivity than the average graduate (European Commission, 2013). This strongly indicates the relationship between employability skills and organizational success.

The two major concerns for employers when it comes to graduate recruitment are, hiring the right graduate and then providing them training for soft skills (Matsouka and Mihail, 2016). Bridgestock (2009) identifies soft skills as being imperative for gainful employment and career advancement. Therefore, employees with these skills are in demand and are considered valuable human capital assets to companies. Jobstreet.Malaysia (2015), reported that a staggering 64 per cent of employers in Malaysia mulled over graduate candidates with unrealistic salary expectation and another 60 per cent complained of poor professionalism. The report also said 50 per cent of employers in the country cited poor communication skills and a poor command of the English language. The same survey identified 70 per cent of respondents who said that the competence demonstrated by graduates at work were just average, whilst 24 per cent said they were of poor quality and only six per cent said that their hires were competent.

This study synthesised relevant and current literature and proposed a conceptual framework 
for the present context as illustrated in Figure 1 page 5. In this regard, the framework comprises of soft skill as a main independent construct, three sub-constructs namely communication, leadership, problem solving and teamwork and one dependant construct, which is, graduate employability. In the following sections, these constructs are delineated specifically.

\subsection{Soft-Skills}

Robles (2012) asserted the importance of soft skills for organisational success and from the employers' perspective it is a necessary attribute for graduates to have. The researcher also defined soft skills as a range of generic skills such as communication, leadership and teambuilding. Nusrat (2016); Taylor (2017), posited that in addition to soft skills or generic skills, personality attributes of a more intrinsic nature such as the commitment level of a person towards an organization or leading and completing a task that has been entrusted to an individual are also important. Interestingly, Holtbrugge and Mohr (2010) pointed out that an individual's ability to develop meaningful work relationships is also a key soft skill, which may equally add value to the workplace. Johnson, (2014) identified soft skills to include public speaking, presentation skills and problem solving. Pham et al., (2018) concurred on this viewpoint and further extended the definition of soft skills to also include the ability to reason and think rationally. Their study also revealed that personal attributes and good work ethics such as punctuality and trustworthiness as highly valued by employers but went on to add that these did not fall within the ambit of soft skills but rather attributes of an intrinsic nature.

Clifford and Montgomery (2014), offered to clarify the meaning of effective communication to include eloquent and confident speaking, effective listening skills and the ability to offer empathy to others. Shafie, Syed Khuzzan and Mohyin (2014), identified five soft skills as being critical success factors for better graduate employability within the Malaysian context. These skills include communication skills, creative and critical thinking, team work, professional attitude, decision making and problem solving skills. Additionally, Kati (2017), reported that communication skills is undoubtedly important and indicated a significant relationship between good communication and organisational efficiency.

Drawing from the discussion above, on soft skills, the following soft skills have been consistently and frequently identified: (i) communication (ii) leadership, (iii) problem solving and (iv) teamwork, which will be discussed in greater detail in the next section.

\subsubsection{Communication}

National Association of College Education United Kingdom, (2009) conducted a survey on employers and reported its findings that communication was the most important skill for graduates in the workplace and regrettably was reported to be the one skill which graduates were most deficient in. Good interpersonal skills and formal and informal methods of communication are amongst the list of soft skills that will additionally contribute to a person's social duties (Nepal, 2010). Good communication is considered as the foundation of strong, healthy interpersonal relationships (Hoe and Jangwan, 2016). Employers place high 
value on those who have good written and spoken communication skills and many identify such skills as a key job requirement (Mascle, 2013; Towers-Clark, 2015). Towers-Clark (2015), emphasises the importance of oral communication and how it helps in presenting ideas with clarity and force. It is a skill that is key for presenting ideas, motivating a team, strategizing, managing or chairing meetings and communicating across a diverse group of employees within an organization (Garwood, 2012). Communication is therefore, a critical skill for graduates to acquire in order to gain access to the workplace regardless of positions or industries they consider (Miller, Biggart and Newton, 2013).

\subsubsection{Leadership}

The meaning of leadership is the achievement of goals through harnessing the work and talents of a team (Prieto, 2013). Leadership is necessary for negotiation, to influence and to render service to customers and even to resolve disputes (Weber et al., 2017). Hu and Liden (2011) argue that leadership training incorporated in undergraduate studies has proven to positively influence a student's potential leadership qualities. Similarly, Lok and Crawford (2004) concur that such leadership qualities in graduates are useful in the workplace and is therefore an important aspect of their undergraduate curriculum. The researchers strongly recommend that HEIs develop a curriculum to include discipline-specific coursework, work integrated learning components such as internship and experiential learning. Tiraieyairi and Abdul Hamid (2015) argued that leadership is a significant predictor for employability orientation.

\subsubsection{Problem Solving}

Problem solving is the highest and most complex level of learning. The thinking process in problem solving may require skills to process and organise the information obtained for problem solving. Possessing a problem solving skill may indicate that an individual is able to think critically, logically and creatively and be able to see things from multiple perspectives (Syafii and Yasin, 2013). Problem solving has been described as the cognitive-affective-behavioural process by means of which individuals reportedly identify, discover, or invent effective or adaptive coping responses for specifically problematic situations (Wang and Chiew, 2010). Problem solving is thus the ability to plan, organize, take action, evaluate and adopt. Being a problem solver may have a significant influence on one's success in life (Belzer, D'zurilla and Maydeu-Olivares 2002). Being a problem solver reportedly requires the capacity to define an interpersonal problem, to generate possible solutions, and to make a rationally founded choice among solutions which may culminate in the desired goal (Hoe and Jangwan, 2016).

\subsubsection{Teamwork}

Teamwork has become the norm of today's workplace, and teamwork skills are often cited as key criteria for hiring (Brock et al., 2017). Its emerging importance in the workplace has resulted in firms showing more interest in hiring people with team skills (Agwu, 2015). Teamwork bears much benefit at the workplace such as improved workplace productivity, enhanced overall creativity, reduced response times, better decision-making and problem 
solving (Agwu, 2015;Ahles and Bosworth, 2004; McEwan et al., 2017). Despite its many benefits, working in teams poses its own unique challenges such as compliance to deadlines (Brock et al., 2017) poor diversity management and miscommunication (Agrawal, 2012; Payne et al., 2013). Teamwork has been acknowledged as being one of the major skills involving workforce readiness and has become an integral part of the education (Ahles and Bosworth, 2004).

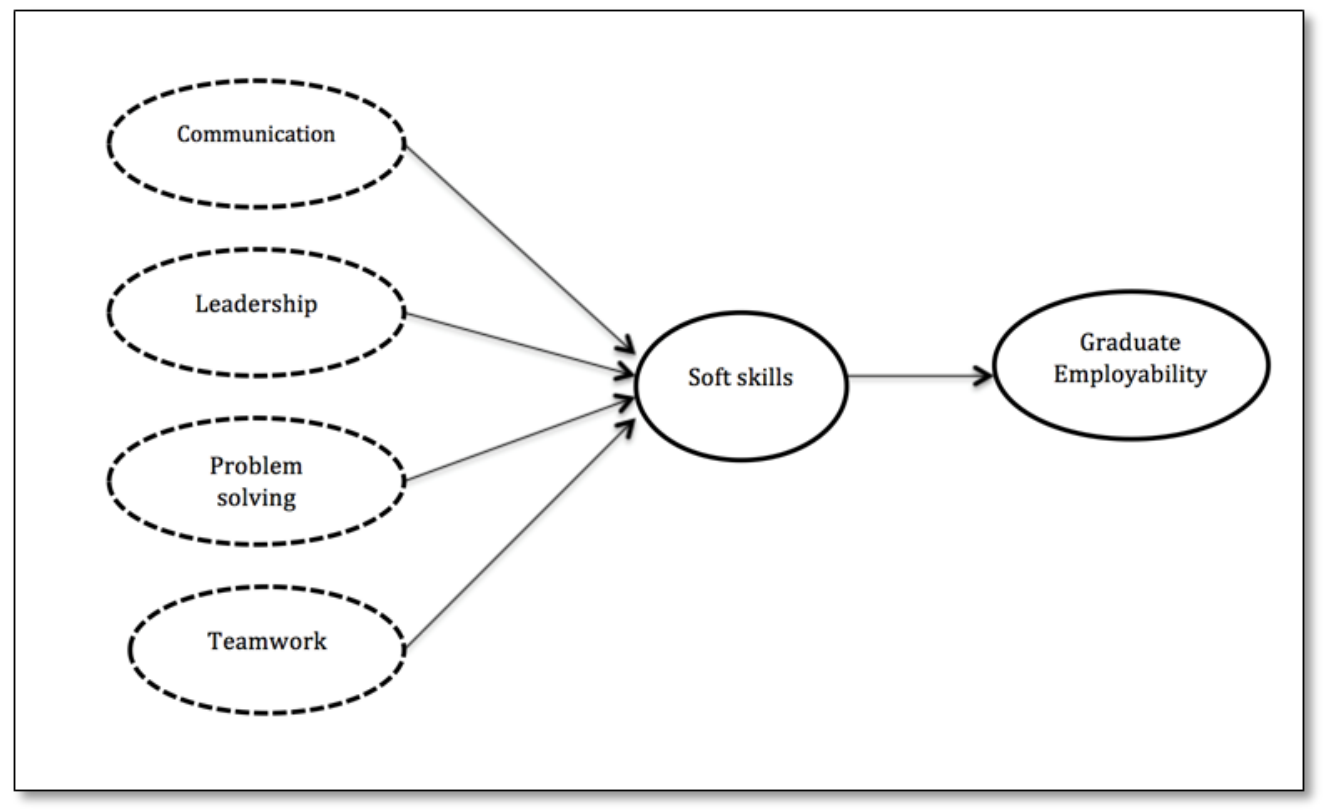

Figure 1. Proposed Conceptual Framework

\section{Methodology}

\subsection{Qualitative}

The qualitative approach was employed as this study is descriptive and explorative in nature, which, reflects the interpretive approach (Denzin and Lincoln, 2018). Besides, data derived from the qualitative approach offers in-depth perspective for the issues highlighted (Blumberg, Cooper and Schindler, 2008). The qualitative technique was applied here 'to attain detailed information regarding certain phenomena like emotions, feelings, and thought processes' (Corbin and Strauss, 1998, p. 11). Additionally, Saldana (2011) asserted that qualitative inquiry penetrates the surface of a research scope. The qualitative approach permits one to identify, explore, and clarify the variable(s) that demand further evaluation, besides providing the phenomenon description in detail based on the viewpoints given by the respondents (Tharenou, Donohue and Cooper, 2007). Practically, this approach has been widely carried out by using the methods of in-depth interviews and focus group sessions in seeking answers to 'why and how' questions in any research (Bryman and Bell, 2015).

\subsubsection{Sampling}

As this study was exploratory in nature, collecting the widest range of data possible with participation by a diverse range of participants was necessary (Creswell and Plano Clark, 2011; Saldana, 2011). Therefore, a purposeful sampling technique, employing a 
non-probability sampling strategy, considered suitable for a naturalistic enquiry was used to recruit informants. This is a commonly used method in qualitative research for the purpose of identifying and selecting information-rich cases for the most effective use of limited resources (Patton, 2014). Purposeful sampling involves a sample group of individuals and groups because they are very knowledgeable and have experience in a phenomenon of interest (Creswell and Plano Clark, 2011). The criteria for participants were those with at least ten years of relevant working experience, in leadership position with direct hands-on management of graduates and representing a cross-section of industries.

\subsubsection{Data Collection}

All interviews were digitally recorded and transcribed. Using the transcribed interview scripts the researchers then proceeded to read and re-read to capture themes and identify each theme using number/name/colour codes. The second stage involved the reduction process by consolidating overlapping themes. The interview files saved in word format is imported to ATLAS.ti which is a computer assisted qualitative data analysis software (CAQDAS) and the researcher then manually reads and re-reads, noting topics and assigning these topics with code names and code colour using the applications in ATLAS.ti.

\subsubsection{Data Analysis}

The thematic analysis of this study was performed using ATLAS.ti, that allows for the simultaneous reading, coding, analysis or memo-ing of a document by researchers. Patton (2014) highly recommends the thematic analysis as it promotes an analysis that is rich and complete. In addition, Saldana (2011) also suggests that thematic analysis is commonly used in the fields of business and social science. The thematic analysis embeds identification of themes to determine emerging patterns or themes. These themes are identified, by highlighting any repeating ideas from the responses. Furthermore, similar ideas are categorized within the same theme.

\subsubsection{Participant Profile}

As noted, ten participants took part in in-depth interviews. Pseudonyms are used throughout the discussion of findings for confidentiality (Kaiser, 2009). Table 1 below presents the profile of participants

Table 1. In-depth interview respondent profile

\begin{tabular}{|c|c|c|c|c|c|}
\hline No & Participant & Position & Profile & $\begin{array}{c}\text { No. of } \\
\text { employees }\end{array}$ & Sector \\
\hline 1 & A & CEO & Female, 49 & 42 & $\begin{array}{c}\text { Media and } \\
\text { publications }\end{array}$ \\
\hline 2 & B & CEO & Male, 62 & 35 & $\begin{array}{c}\text { Information } \\
\text { Technology }\end{array}$ \\
\hline 3 & C & CEO & Male, 44 & 30 & $\begin{array}{c}\text { Telecommunications } \\
\text { and Engineering }\end{array}$ \\
\hline
\end{tabular}




\begin{tabular}{|c|c|c|c|c|c|}
\hline 4 & D & Manager & Male, 48 & 120 & $\begin{array}{c}\text { Accounting and } \\
\text { Taxation }\end{array}$ \\
\hline 5 & $\mathrm{E}$ & Vice President & Male, 61 & 3000 & $\begin{array}{c}\text { Banking and } \\
\text { Finance }\end{array}$ \\
\hline 6 & $\mathrm{~F}$ & Head of Department & Female, 37 & 350 & Education \\
\hline 7 & $\mathrm{G}$ & Managing Partner & Male, 49 & 55 & Training and \\
\hline 8 & $\mathrm{H}$ & Development \\
\hline 9 & $\mathrm{~J}$ & Hiring Manager & Female, 35 & 500 & Pharmaceutical \\
\hline 10 & $\mathrm{~K}$ & Head & Female, Human & 2,500 & Automobile \\
\hline
\end{tabular}

\section{Results}

Drawing on existing literature and past research, an initial framework was conceptualised illustrating the multidimensional structure of graduate employability as depicted in Figure 1. A thematic analysis was carried out and new dimensions comprising of a main construct and three sub-constructs were discovered and added to form the enriched graduate employability framework as illustrated in Figure 2. Findings of the construct and its sub-constructs are further discussed in the subsequent section.

\subsection{Graduate Training}

Five participants of the interviews reiterated graduate training as an important dimension of graduate employability and its significance was reflected in their responses. The graduate training element is an interesting finding as it highlights the magnitude and severity of the research problem, which states that graduates are not work-ready. Skill shortage is such an acute problem that employers are willing to take on the responsibility of training the graduates themselves. Although it involves a substantial financial investment, employers have recognised their purposeful role in assisting graduates to develop the skills required for being work-ready (Van Buren, 2003; Wittekind, Raeder and Grote, 2010). Companies that help the developmental process of an employee have a higher chance of achieving better workforce productivity and competitive advantage hence resulting in better financial returns (Clarke, 2016). Connor and Shaw (2008) proposed the transfer of learning, and much of learning itself, is most effective when the context most closely mirrors that in which it is to be applied. The following are quotations of some of the interviews with the corresponding Atlas.ti codes:

Training is a very important part of graduate and employee development. ....new graduates go through a rigorous programme where they are taught a range of skills like, leadership, communication, customer care, ethics etc. E; 3:1

The respondent narrowed the scope of the discussion on training to a more specific dimension, which focuses on employability skills by itself. The role of training programs according to 
participant $\mathbf{E}$, acts as a conduit to transfer knowledge and skills to the new graduates (Laker and Powell, 2012). By implementing training programs, knowledge and skills can be shared between employers or industrial experts and employees. Below are excerpts of some of the interviews with participants $\mathbf{A}, \mathbf{C}$ and $\mathbf{D}$.

I'm a firm believer in training graduates. If we want them to have certain skills and competencies that are especially relevant in our particular line of work, then obviously we have to train them so they can learn those new skills. A; 8:3

Training is imperative for graduates now. I remember when I first graduated, there was no such thing as graduate training. Today, however, soft skills are so important in client retention and customer relationship management but graduates don't seem to have those skills. C; 2:1

In my opinion, it is important for the organization to conduct a proper and formal training programme for the graduates. The Universities seem to be failing, so what choice do we have? If we want the graduates to have a particular skill-set and knowledge, then I guess we have to provide them the training. $\mathbf{D ;}$ 7:2

From the above narratives, what can be derived is that graduate training can become a well-established strategy for employers to recruit graduates. Graduates find the promise of career development opportunities and formal training as attractive aspects of a job (Clarke, 2016). The study also uncovered other elements to graduate training, such as internship, mentoring and talent management. The next segment will consider each of these variables.

\subsection{Internship}

Internship was frequently highlighted by the participants as being a key employability factor. A few participants provided insight as to how it should be managed and structured by the HEIs to yield better results. Below are excerpts of some of the interviews:

I find those with internship experience perform a lot better than those without. Personally I prefer to hire interns and train them and then I offer permanent positions to those I feel have good potential. A; 8:1

Internship is a very good initiative by the Universities in preparing the student for the real world. It gives them the well-needed work experience that no amount of classroom teaching can replace.

\section{B; 9:1}

Internship is a very good training ground for the students. I am a strong advocate of internship and I do take in interns on a regular basis from the public universities. ..The good ones I re-hire as permanent once they complete their degrees and show interest to work with me again. D: $7: 1$

Internship helps to give the students a real world working experience, which helps them later on to get jobs. $\mathbf{J} ; \mathbf{4 : 2}$ 
These findings concerning internship, reflect the importance of work experience and how it enhances graduate employability. From the observer's point of view, the enthusiasm and positivity that resonated from the employers, demonstrated their firm support and belief towards the internship initiative. Internship is a form of work integrated learning experience, which provides the student the experience of applying a theoretical philosophy to a hands-on, real-life leadership situation. The symbiosis of theory and practice increases the learning outcome of internships (Deschaine and Jenkins, 2017). Callanan and Benzing (2004) report that there is a positive relationship between internship and employability and increased earnings in subsequent employment. Maelah et al., (2014) provide support to this notion by reporting that the employer benefits by having an opportunity to identify possible future employees. It can be concluded from the above narratives that internship does indeed have an influence on graduate employability.

\subsection{Mentoring}

The interviews revealed the importance of mentoring of a new graduate by a senior employee. They shared that mentoring programs has gained popularity in workplaces, because it has been proven to reduce turnover, promote growth, and assist employees to adjust to new jobs and progress in their careers. This finding is consistent with Chang and Busser (2017), that mentoring programmes have been proven to increase personnel retention and career satisfaction, accelerate the development of leadership, and reduce the learning curve in response to today's more demanding, competitive, and global markets. It is for this reason that 71 percent of Fortune 500 companies offer mentoring programs, showing that mentoring programs are becoming a standard in many workplaces (Kantor and Crosser, 2017). Mentoring is known to establish good and consistent work behavior and practices in the workplace (Darwin, 2015).

Comments from $\mathbf{J}$, hiring manager of a multinational automobile confirmed this as follows:

We do have a 'Buddy' system, where we pair up a new graduate appointee with a high performing senior employee....we find the Mentoring Porgramme to be highly successful, in developing new graduates to our expected standards. J; 4:4

Similar sentiments on the importance of mentoring were echoed by participants $\mathbf{D}, \mathbf{F}$ and $\mathbf{G}$. Excerpts of the interview are presented below.

...I believe that every senior member should undertake to mentor new graduates ...I find mentoring a very good initiative ....helps in staff retention as well. D; 7:3

I believe this is evident in the success that the mentoring program has been running for the last five years with great results and continues to keep running. I feel honoured to be part of this. F; 5:1

Being able to overcome hurdles guidance and feedback from the mentor is invaluable as a new graduate, where everything is totally new. I just find it so rewarding to know that I have given them the confidence to believe in themselves. $\mathbf{G} ; \mathbf{6 : 2}$

While mentoring is a topic that has been subject to various studies in the past, the question of 
mentoring in relation to graduate employability is under researched. Therefore, the findings offer a fresh perspective to the body of knowledge and is a valuable inclusion to the enriched graduate employability framework. It can be concluded that mentoring graduates does indeed have a positive impact on graduate employability.

\subsection{Talent Management}

Another strong theme that emerged is that of talent management and the vital role it plays in graduate employability. This is in tandem with the findings of McCraken, Currie and Harrison, (2015) which encourages organisations to customise talent management to the particular needs, interests, values, motivations and aspirations of a young and inexperienced workforce. Scott and Revis (2008) postulated that the concept of talent management is considered key, to postmodern business success where graduates are specifically trained based on the business needs. Therefore, talent management is a much required priority for organisations to develop a graduate talent pool.

From the interviews conducted, three employers provided valuable details of their talent management program. Participants $\mathbf{C}$ and $\mathbf{E}$ reveal how a well-structured formalised talent management programme develops high performing graduates and creates a culture of learning and growth within the organisation:

We have a proper programme, called Hi-Pot-TM (High-Potential-Talent-Management). This begins right from recruitment, where the candidates have to go through a pre-recruitment aptitude and attitude test.... C; $2: 2$

The 6 month orientation programme also helps us to further narrow down to a pool of high potential talent who then qualify for our Management Trainee Programme (MTP). They go through a series of skill-based courses, which cover leadership, communication and teambuilding. The MTP is for developing future leaders of the Bank. This programme has been highly successful $\quad$ E; 3:2

G highlighted that such programmes produce a return on investment through client retention and increased customer satisfaction and also helped in branding the organisation as a employer of choice:

We have our own system where we identify the key young talents and invest in them through training and mentoring as was mentioned earlier....This investment has brought about tremendous results and has given us a good name in the market as a preferred employer. $\mathbf{G}$; 6:4

In tandem to Cappelli's (2008) assertion, three of the employers interviewed, identified talent management to manage the graduate's shortfalls in skill and experience. However, to overcome the risk of managing talent inefficiently, the interviewees explain that they have increased the exclusivity of their graduate talent programmes by refining the criteria to participate in such programmes. Such opportunities are exclusive for graduates who demonstrate high potential.

On the importance of a graduate talent management programme, the commentaries from the 
above interviews, converge on four main points which the researcher is able to summarise as i) Building a high performance workplace; ii) Encouraging a learning organisation, iii) Identifying as an employer of choice; iv) Ensuring return on investments in training and development. The participants are unanimous in suggesting that graduates are a key source of talent within many organisations and through talent management they can be developed into high performing employees. However, organisations have been impervious to the critical significance of talent management as a graduate developmental strategy.

The interview transcripts from the in-depth interviews were manually read and re-read and coded according to themes and colour for easy reference using the ATLAS.ti. Each code was linked to direct quotations from the interviews using the 'quotation manager' feature, which made it fast and efficient in getting excerpts accurately. Recurring codes meant repeating ideas and helped to establish major themes. Three new themes were identified and are presented below in Table 2 with key words from the quotations.

Table 2. Key words elicited from thematic analysis of qualitative phase

\begin{tabular}{|c|c|c|}
\hline $\begin{array}{c}\text { New Emerging } \\
\text { Themes }\end{array}$ & Key words from Interviews & Atlas.ti Code \\
\hline \multirow[t]{4}{*}{ Graduate training } & firm believer in training graduates & $A ; 8: 3$ \\
\hline & $\begin{array}{l}\text { it is important ..to conduct a proper. training } \\
\text { programme for the graduates }\end{array}$ & $D ; 7: 2$ \\
\hline & Training is imperative for graduates now & $C ; 2: 1$ \\
\hline & $\begin{array}{l}\text { Training is a very important part of graduate and } \\
\text { employee development }\end{array}$ & $E ; 3: 1$ \\
\hline \multirow[t]{4}{*}{ Internship } & $\begin{array}{l}\text { Graduates with internship experience perform a } \\
\text { lot better }\end{array}$ & $A ; 8: 1$ \\
\hline & $\begin{array}{l}\text { Internship is a very good initiative ..in preparing } \\
\text { the student for the real world }\end{array}$ & $B ; 9: 1$ \\
\hline & Internship is a very good training ground & $D ; 7: 1$ \\
\hline & $\begin{array}{l}\text { Internship helps to give the students a real world } \\
\text { working experience }\end{array}$ & $J ; 4: 2$ \\
\hline \multirow[t]{4}{*}{ Mentoring } & $\begin{array}{l}\text { every senior member should undertake to mentor } \\
\text { new graduates }\end{array}$ & $D ; 7: 3$ \\
\hline & mentoring program ...great results & $F ; 5: 1$ \\
\hline & mentoring highly successful & $J ; 4: 4$ \\
\hline & $\begin{array}{l}\text { guidance and feedback from the mentor is } \\
\text { invaluable }\end{array}$ & $G ; 6: 2$ \\
\hline \multirow[t]{4}{*}{ Talent management } & high performing graduates & $C ; 2: 2$ \\
\hline & highly successful & $E ; 3: 2$ \\
\hline & tremendous results & $G ; 6: 4$ \\
\hline & a good name... as a preferred employer. & $G ; 6: 4$ \\
\hline
\end{tabular}

Therefore, the key findings that emerged from the qualitative phase that used in-depth interviews to explore perceptions of the employers on graduate employability elements are discussed further. Figure 2 illustrates the enriched graduate employability dimensions and guides the detailed findings of each variable. By drawing on existing literature and past research, an initial framework was conceptualised illustrating the multidimensional structure 


\section{Macrothink Institute ${ }^{\mathrm{TM}}$}

of graduate employability as depicted in Figure 1. From the qualitative research that was subsequently conducted, a thematic analysis was carried out and newly identified and enriched constructs and sub-constructs have been added to form the enriched graduate employability framework. The new constructs and sub-constructs are identified below in the 'dotted boxes' Figure 2.

One of the objectives of this study was to gain insights into the experiences and perceptions of the employers in developing an enriched graduate employability framework. This paper presents various elements that impact graduate employability and from the findings of this study, the initial conceptual framework derived from literature review is maintained. However, there is an additional salient construct identified from this qualitative phase to be incorporated into the initial conceptual framework. The new construct 'graduate training' consists of sub constructs such as 'Internship', 'Mentoring' and 'Talent Management' which would be embedded into the existing conceptual framework to now form the enriched employability framework.

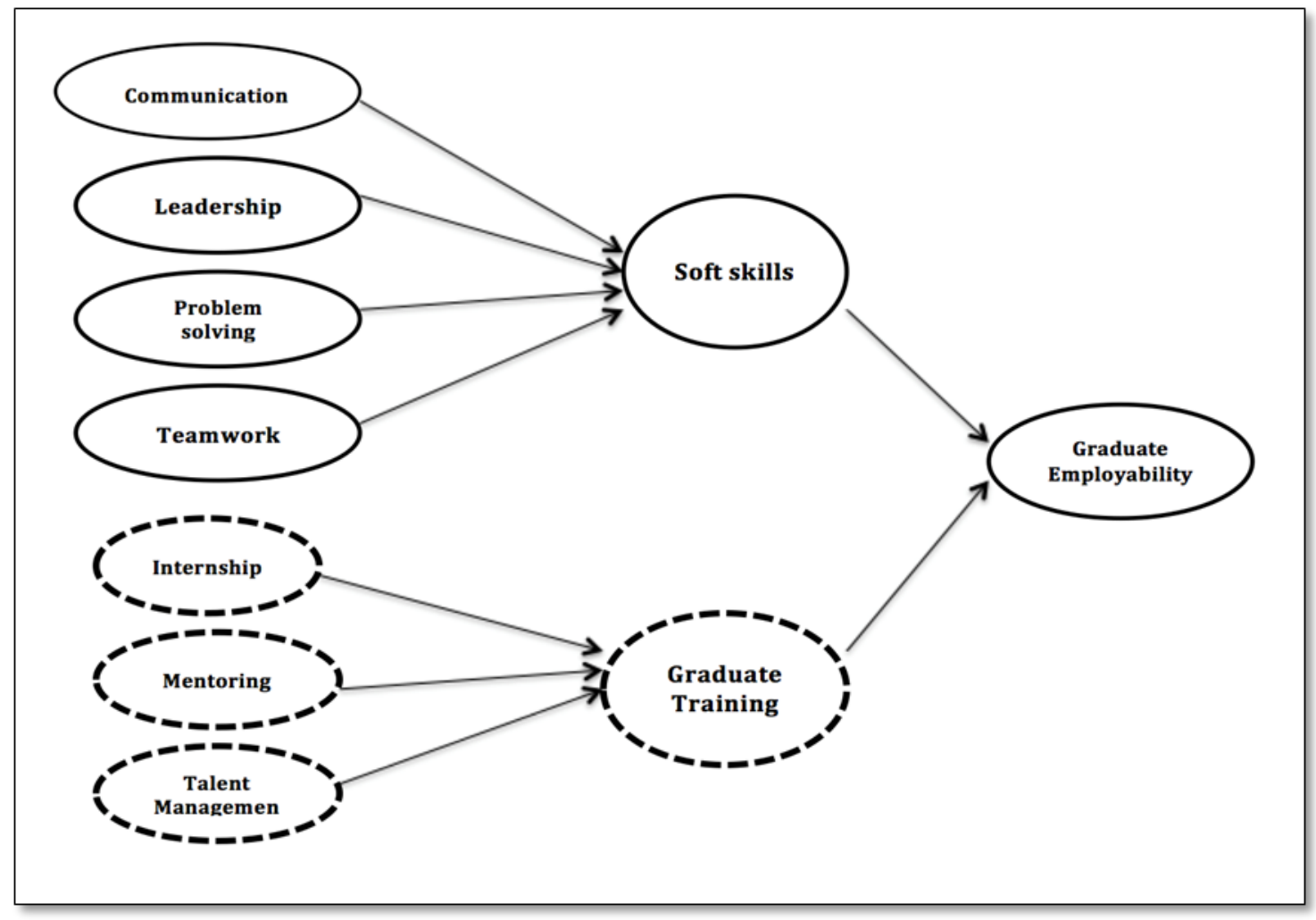

Figure 2. Enriched graduate employability framework

\section{Discussion}

This study examined the employer stakeholder viewpoint, the findings of which then contributed the basis of an enriched framework of graduate employability. The enriched framework does more than just extend current body of knowledge of the graduate employability concept; it provides a new contemporary working framework for use in practice. This research has found that previous employability models require modification to 
include the significant construct of 'graduate training' and its sub-constructs 'internship' 'mentoring' and 'talent management'. This enriched framework brings these previously omitted elements to the forefront. Furthermore, this research contributes in addressing the problems around graduate employability and its applicability to a variety of individuals and groups who have precipitous vested interest in this enriched graduate employability framework: students, graduates, academic staff, HEI management, employers and policy makers. It must be reiterated that the implications appended in the sections below are proposed from a Malaysian viewpoint.

\subsection{Implications for HEIs}

HEIs need to address the critical issues as enunciated by the enriched graduate employability framework developed in this study. HEIs should undertake a developmental approach that focuses on designing a curriculum that enables students to develop competence in the soft skills identified in this study such as communication (written and spoken), teamwork, problem solving and leadership. The findings concerning internship reflect the importance of work experience and how it enhances graduate employability. Employers expressed their firm support and belief towards the internship. It's a form of work integrated learning experience, which provides the student the experience of applying a theoretical philosophy to a hands-on, real-life leadership situation. The symbiosis of theory and practice increases the learning outcome of internships.

The findings also reveal that many internship programs still do not offer the experiences that successfully prepare graduates to be work-ready. So, despite the potential benefits behind the internship program, some internship experiences simply do not deliver the desired results (Jackson, 2016). Hence, there are several ways in which this initiative should be addressed. There needs to be dialogue between HEIs and employers in relation to internships' optimum duration, performance management issues, and both macro and micro aspects of guidance in augmenting the whole internship process.

The above implications are predicated due to some experiences described to be unchallenging, scattered, routine, or career-irrelevant. This, along with poor workplace practices that offer little or no learning, closer to personal servitude (Jackson, 2016), can act to provide no value, or even cause harm, for the intern.

\subsection{Implications for Public Policy (Government)}

The Ministry of Higher Education Malaysia (MoHE) must work towards development of soft skills through core modules where the soft skill element is embedded into the curriculum and in the method of delivery. Greater emphasis needs to be placed on elements such as presentations, debates, writing, teamwork and problem solving inter alia. The relevant Government agencies need to propose legislation to develop lecturers' teaching skills in relation to soft skills identified in this study. As mentioned by respondent interviewee $\mathbf{A}$

As I know, most academics themselves have not worked in industry environments, so how can they possibly hope to prepare the students to be work ready? A; 8:5 
Setting up of the Industry Advisory Panel comprising of industry and corporate leaders and curriculum developers and academic leaders in assisting the HEIs to develop a more relevant curriculum. A strong drive towards enhancing HEI and business collaboration can be viewed as a solution. A good collaborative relationship would provide an avenue for the employer to input into curriculum development and prescribe effective assessment methods. Close links with the industry also helps establish communication channels for both parties to provide feedback with a view to improving the responsiveness of education and training systems, and provision, in meeting the needs of national labour markets.

The graduate training element is a significant discovery in this research as all participants of the in-depth interviews reiterated its important role in equipping new graduates with employability skills. The following are two sample quotations:

In my opinion, it is important for the organization to conduct a proper and formal training programme for the graduates. D:;7:2

I'm a firm believer in training graduates. If we want them to have certain skills and competencies that are especially needed in our particular line of work, then obviously we have to train them. A: 8:3

Although it involves a substantial financial investment, employers have recognised their significant role in assisting graduates to build and maintain the range of skills required to succeed in current and prospective employment (Van Buren, 2003; Wittekind et al., 2010). In tandem with this, relevant government authorities such as the Ministry of Human Resource Development, can structure workshops and courses on 'Work-ready Certification' or 'Introduction to Work Place Skills Certification' to help new graduates prepare for work through employability training and work placement, which results in a nationally recognised qualification upon completion. This qualification will be tailored to enable new graduates to develop employability skills and begin to improve their competence in a workplace environment.

\subsection{Implications Employers}

The paper emphasises the claim that employers play a formidable role in graduate employability. The findings reveal that employers are not solely reliant on the HEIs to produce the graduates with industry required skills but through graduate training the employers themselves have the ability to develop the kind of graduates with the required skills and abilities.

Providing relevant graduate training to new recruits, mentoring and managing new graduate talent are important aspects of employer involvement in developing graduate employability. Offering graduate training opportunities is a crucial step that employers need to take which would benefit all employability stakeholders. HR practices in regard to graduate training must be designed carefully to incorporate the soft skills identified. Although this could involve financial investment, employers have recognised its significant role in developing work-ready graduates. 
A new theme that emerged among the respondents is that of talent management and the role it plays in graduate employability. McCracken, Currie and Harrison, (2015) postulated that talent management is key, to postmodern business success where graduates are trained towards industry needs and that it is a viable strategy towards developing graduate talent to manage sophisticated consumer demands. Indeed, according to Tafti, Mahmoudsalehi and Amiri (2017), good talent management schemes across businesses within a sector, will ultimately enhance business practices and competitiveness. Highly employable graduates can enable organisations to meet fluctuating global demands for goods and services by adopting new roles and acquiring new skills. Through talent management, organisations can develop an employability orientation amongst graduates and employees (Tafti, Mahmoudsalehi and Amiri (2017).

\section{Conclusion}

The study thus offers insights into the employers' perspective of graduate employability and it is clear that graduate employability is arguably more complex now than ever before, given the greater demands of the business community and increased competition. Graduate training enhances graduates' knowledge and skills and this as a result increases knowledge capital and competitiveness of organisations (McDermott et al., 2006).

This study has aimed to set the scene for future research on current trends in graduate training and other dimensions of graduate training such as internship, mentoring and talent management. It has highlighted the need for companies to look seriously into graduate learning and development and for HEIs to continue to strengthen its courses to transfer the skills which employers' value and to create an awareness of current trends and needs of the labour market. Employers and HEIs need to strengthen its collaboration so that their expectations of graduates can easily be conveyed from time to time. They also need to reposition their learning and development approach and method for graduate recruits to not just meet their business needs but also to fulfill graduate expectations. Another area for future work could involve carrying out an empirical study on graduates about their perceptions of employability. This research could employ an online questionnaire technique to fresh graduates in ascertaining their level of congruence in relation to the employers' perception as exemplified by this enriched graduate employability framework. Secondly, there can be a triangulation carried from the findings in relation to viewpoints from HEIs. The culmination of the overall study on graduate employability should be the reconciliation of all the above findings in identifying an overall "Hybrid Graduate Employability Model".

The corresponding author deeply thanks Ms. Vanitha Samuel for her comments.

\section{References}

Agrawal, V. (2012). Managing the diversified team: challenges and strategies for improving performance",. An International Journal, Vol. 18(7/8), pp.384-400. https://doi.org/10.1108/13527591211281129

Agwu, D. (2015). Teamwork and Employee Performance in The bonny Nigeria Liquefied Natural Gas Plant. Strategic Management Quarterly, 3(4). 
https://doi.org/10.15640/smq.v3n4a3

Ahles, C., \& Bosworth, C. (2004). The Perception and Reality of Student and Workplace Teams. Journalism \& Mass Communication Educator, 59(1), 41-59. https://doi.org/10.1177/107769580405900108

Bank Negara Malaysia. (2017). Youth Unemployment in Malaysia: Developments and Policy Considerations (pp. 100 - 101). Kuala Lumpur: Bank Negara Malaysia. Retrieved from http://www.bnm.gov.my/files/publication/ar/en/2016/cp04_003_box.pdf

Belzer, K., D’Zurilla, T., \& Maydeu-Olivares, A. (2002). Social problem solving and trait anxiety as predictors of worry in a college student population. Personality And Individual Differences, 33(4), 573-585. https://doi.org/10.1016/s0191-8869(01)00173-8

Blumberg, B., Cooper, D., \& Schindler, P. (2008). Business Research Methods. London: McGraw-Hill Education.

Bridgstock, R. (2009). The graduate attributes we've overlooked: enhancing graduate employability through career management skills. Higher Education Research \& Development, 28(1), 31-44. https://doi.org/10.1080/07294360802444347

Brock, S., McAliney, P., Ma, C., \& Sen, A. (2017). Toward more practical measurement of teamwork skills. Journal Of Workplace Learning, 29(2), 124-133. https://doi.org/10.1108/jwl-07-2016-0069

Bryman, A., \& Bell, E. (2015). Business Research methods (4th ed.). Oxford: Oxford University Press.

Callanan, G., \& Benzing, C. (2004). Assessing the role of internships in the career-oriented employment of graduating college students. Education + Training, 46(2), 82-89. https://doi.org/10.1108/00400910410525261

Cappelli, P. (2008). Talent Management for the Twenty-First Century. Retrieved from https://hbr.org/2008/03/talent-management-for-the-twenty-first-century

Chang, W., \& Busser, J. (2017). Hospitality employees promotional attitude: Findings from graduates of a twelve-month management training program. International Journal of Hospitality Management, 60, 48-57. https://doi.org/10.1016/j.ijhm.2016.09.013

Clarke, M. (2016). Building employability through graduate development programmes. Personnel Review, 46(4), 792-808. https://doi.org/10.1108/pr-12-2015-0321

Clifford, V., \& Montgomery, C. (2014). Challenging Conceptions of Western Higher Education and Promoting Graduates as Global Citizens. Higher Education Quarterly, 68(1), 28-45. https://doi.org/10.1111/hequ.12029

Connor, H., \& Shaw, S. (2008). Graduate training and development: current trends and issues. Education + Training, 50(5), 357-365. https://doi.org/10.1108/00400910810889048

Copps, J., \& Plimmer, D. (2013). Inspiring Impact: Journey to EmploymenT (JET) 


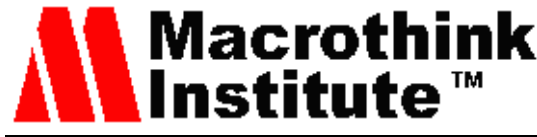

International Journal of Human Resource Studies

ISSN 2162-3058

2018, Vol. 8, No. 4

framework (pp. 4 to 17). London: New Philanthropy Capital (NPC). Retrieved from https://www.thinknpc.org/publications/the-journey-to-employment/

Corbin, J., \& Strauss, A. (1998). Basics of qualitative research (p. 11). SAGE.

Creswell, J., \& Plano Clark, V. (2011). Designing and conducting mixed methods research (2nd ed.). Thousand Oaks, California: Sage.

Critical Occupation List: Addressing Malaysia's Talent Shortages. (2016). Retrieved from https://www.talentcorp.com.my/clients/TalentCorp_2016_7A6571AE-D9D0-4175-B35D-99 EC514F2D24/contentms/img/publication/MSJ16050704.pdf

Dacre Pool, L., \& Sewell, P. (2007). The key to employability: developing a practical model of graduate employability. Education + Training, 49(4), 277-289. https://doi.org/10.1108/00400910710754435

Dacre Pool, L., Qualter, P., \& Sewell, P. (2014). Exploring the factor structure of the CareerEDGE employability development profile. Education + Training, 56(4), 303-313. https://doi.org/10.1108/et-01-2013-0009

Darwin, A. (2015). Graduates giving back - a mentoring program for MBA students. International Journal Of Mentoring And Coaching In Education, 4(3), 200-212. https://doi.org/10.1108/ijmce-03-2015-0009

De Vos, A., De Hauw, S., \& Van der Heijden, B. (2011). Competency development and career success: The mediating role of employability. Journal Of Vocational Behavior, 79(2), 438-447. https://doi.org/10.1016/j.jvb.2011.05.010

Denzin, N., \& Lincoln, Y. (2018). The Sage handbook of qualitative research. Los Angeles: SAGE.

Deschaine, M., \& Jankens, B. (2017). Creating successful and sustainable educational administrative internship experiences. Higher Education, Skills And Work-Based Learning, 7(1), 5-20. https://doi.org/10.1108/heswbl-02-2016-0008

Economic Planning Unit. (2015). Anchoring Growth on People. (p. 6). Kuala Lumpur: Percetakan Nasional Malaysia Berhad, $\quad$ Retrieved from http://www.epu.gov.my/sites/default/files/11MP\%20Summary\%20BI.pdf

European Commission. (2013). The Employability of Higher Education Graduates: The Employers'Perspective.. Maastricht: Research Centre for Education and the Labour Market.

Garwood, R. (2012). Supporting the underperforming manager. Human Resource Management International Digest, 20(1), 39-42. https://doi.org/10.1108/09670731211195963

Govender, C., \& Wait, M. (2017). Work integrated learning benefits for student career prospects - mixed mode analysis. South African Journal Of Higher Education, 31(5). https://doi.org/10.20853/31-5-609

Govindaraju, C., \& Wong, C. (2011). Patenting activities by developing countries: The case 
of Malaysia. World Patent Information, 33(1), 51-57. https://doi.org/10.1016/j.wpi.2010.01.001

Hanapi, Z., \& Nordin, M. (2014). Unemployment among Malaysia Graduates: Graduates'Attributes, Lecturers' Competency and Quality of Education. Procedia - Social And Behavioral Sciences, 112, 1056-1063. https://doi.org/10.1016/j.sbspro.2014.01.1269

Harvey, L. (2001). Defining and Measuring Employability. Quality In Higher Education, 7(2), 97-109. https://doi.org/10.1080/13538320120059990

Hillage, J., \& Pollard, E. (1998). Employability: developing a framework for policy analysis. Great Britain, Department for Education and Employment.

Hoe, P., \& Jangwan, K. (2016). Relationship between Collaborative Self-efficacy and Problem-solving Skills of University Students: Mediating Effect of Communication Skills. Journal Of Educational Innovation Research, 26(1), 169-192. https://doi.org/10.21024/pnuedi.26.1.201604.169

Holtbrügge, D., \& Mohr, A. (2010). Cultural Determinants of Learning Style Preferences. Academy Of Management Learning \& Education, 9(4), 622-637. https://doi.org/10.5465/amle.2010.56659880

Hu, J., \& Liden, R. (2011). Antecedents of team potency and team effectiveness: An examination of goal and process clarity and servant leadership. Journal of Applied Psychology, 96(4), 851-862. https://doi.org/10.1037/a0022465

Jackson, D. (2016). Developing pre-professional identity in undergraduates through

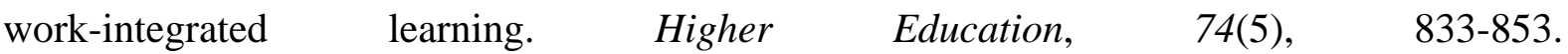
https://doi.org/10.1007/s10734-016-0080-2

Jobstreet. Malaysia. (2015). Employers: Fresh Graduates Have Unrealistic Expectations. Kuala Lumpur: Job street. Malaysia. Retrieved from https://www.jobstreet.com.my/career-resources/employers-fresh-graduates-unrealistic-expect ations/\#.WeXcCUyB3ow

Johnson, K. (2014). Cooperative Education and Sustainability: Students Making a Difference. The International Journal Of Sustainability Education, 9(3), 1-14. https://doi.org/10.18848/2325-1212/cgp/v09i03/55303

Kaiser, K. (2009). Protecting Respondent Confidentiality in Qualitative Research. Qualitative Health Research, 19(11), 1632-1641. https://doi.org/10.1177/1049732309350879

Kantor, J., \& Crosser, A. (2017). Four Key Benefits of Workplace Mentoring Initiatives. Retrieved from https://www.huffingtonpost.com/julie-kantor/four-key-benefits-of-work_b_9432716.html

Kati, S. (2017). Developing Pragmatic Competence While Teaching Communication Skills and Soft Skills for Students' Overall Personality Development. International Journal For Research In Applied Science And Engineering Technology, V(XI), 2823-2826. 
https://doi.org/10.22214/ijraset.2017.11387

Laker, D., \& Powell, J. (2011). The differences between hard and soft skills and their relative impact on training transfer. Human Resource Development Quarterly, 22(1), 111-122. https://doi.org/10.1002/hrdq.20063

Lok, P., \& Crawford, J. (2004). The effect of organisational culture and leadership style on job satisfaction and organisational commitment. Journal Of Management Development, 23(4), 321-338. https://doi.org/10.1108/02621710410529785

Maelah, R., Muhammaddun Mohamed, Z., Ramli, R., \& Aman, A. (2014). Internship for accounting undergraduates: comparative insights from stakeholders. Education + Training, 56(6), 482-502. https://doi.org/10.1108/et-09-2012-0088

Mascle, D. (2013). Writing Self-Efficacy and Written Communication Skills. Business Communication Quarterly, 76(2), 216-225. https://doi.org/10.1177/1080569913480234

Matsouka, K., \& Mihail, D. (2016). Graduates' employability. Industry And Higher Education, 30(5), 321-326. https://doi.org/10.1177/0950422216663719

McCracken, M., Currie, D., \& Harrison, J. (2015). Understanding graduate recruitment, development and retention for the enhancement of talent management: sharpening 'the edge' of graduate talent. The International Journal Of Human Resource Management, 27(22), 2727-2752. https://doi.org/10.1080/09585192.2015.1102159

McDermott, E., Mangan, J., \& O'Connor, M. (2006). Graduate development programmes and satisfaction levels. Journal of European Industrial Training, 30(6), 456-471. https://doi.org/10.1108/03090590610688834

McDermott, E., Mangan, J., \& O'Connor, M. (2006). Graduate development programmes and satisfaction levels. Journal of European Industrial Training, 30(6), 456-471. https://doi.org/10.1108/03090590610688834

McEwan, D., Ruissen, G., Eys, M., Zumbo, B., \& Beauchamp, M. (2017). The Effectiveness of Teamwork Training on Teamwork Behaviors and Team Performance: A Systematic Review and Meta-Analysis of Controlled Interventions. PLOS ONE, 12(1), e0169604. https://doi.org/10.1371/journal.pone.0169604

Miller, L., Biggart, A., \& Newton, B. (2013). Basic and employability skills. International Journal Of Training And Development, 17(3), 173-175. https://doi.org/10.1111/ijtd.12007

Minocha, S., Hristov, D., \& Reynolds, M. (2017). From graduate employability to employment: policy and practice in UK higher education. International Journal Of Training And Development, 21(3), 235-248. https://doi.org/10.1111/ijtd.12105

Morrison, A. (2013). A class act? Lecturers' views on undergraduates' employability. British Journal Of Sociology Of Education, 35(4), 487-505. https://doi.org/10.1080/01425692.2013.802420

National Association of College Education United Kingdom. (2009). Job Outlook 2009 Study. 
London: Ministry of Education UK. Retrieved from http://www.naceweb.org/press/display.asp?year=2009\&prid=295

Nepal, G. (2010). Essence of Ethics in Communication in a Global Climate. The Journal Of The South East Asia Research Centre For Communication And Humanities., 2, 21-31. Retrieved from http://search.taylors.edu.my/final_pdf/journals/Vol2/Vol2_Mar10_4_J3.pdf

Nesaratnam, S., \& Gayen, S. (2018). A Review of Literature on Graduate Employability. The International Journal Of Business And Management, 6(6), 6 -7. Retrieved from http://www.theijbm.com/wp-content/uploads/2018/06/BM1806-001.pdf

Nilsson, S. (2010). Enhancing individual employability: the perspective of engineering $\begin{array}{llll}\text { graduates. } \quad \text { Education } & +\quad \text { Training, } & \text { 52(6/7), }\end{array}$ https://doi.org/10.1108/00400911011068487

Nusrat, M. (2016). Soft Skills for Sustainable Employment; Does It Really Matter?. SSRN Electronic Journal. https://doi.org/10.2139/ssrn.2857520

Patton, M. (2014). Qualitative research \& evaluation methods + writing up qualitative research (4th ed.). United States of America: SAGE.

Pham, T., Bao, D., Saito, E., \& Chowdhury, R. (2018). Employability of international students: Strategies to enhance their experience on work-integrated learning (WIL) programs. Journal Of Teaching And Learning For Graduate Employability, 9(1), 62. https://doi.org/10.21153/jtlge2018vo19no1art693

Prieto, B. (2013). Establishing and Building Leadership Skills. Leadership And Management In Engineering, 13(3), 209-211. https://doi.org/10.1061/(asce)1m.1943-5630.0000235

Rae, D. (2008). Riding out the storm: graduates, enterprise and careers in turbulent economic times. Education + Training, 50(8/9), 748-763. https://doi.org/10.1108/00400910810917118

Rahmat, N., Ayub, A., \& Buntat, Y. (2014). Exploratory Skills Constructs and Dimensions as Job Performance Prediction: A Qualitative Approach. Geografia:Malaysian Journal Of Society And Space, 12(3), 154 - 167.

Rateau, R., Kaufman, E., \& Cletzer, D. (2015). Innovative Classroom Strategies that Prepare College Graduates for Workplace Success. Journal Of Agricultural Education, 56(3), 52-68. https://doi.org/10.5032/jae.2015.03052

Robles, M. (2012). Executive Perceptions of the Top 10 Soft Skills Needed in Today's Workplace. Business Communication Quarterly, 75(4), 453-465. https://doi.org/10.1177/1080569912460400

Saldaña, J. (2015). The coding manual for qualitative researchers + qualitative data analysis (3rd ed.). London: Sage Publications.

Samkin, G., \& Stainbank, L. (2016). Teaching and learning. Meditari Accountancy Research, 24(3), 294-317. https://doi.org/10.1108/medar-05-2016-0062 
Scott, B., \& Revis, S. (2008). Talent management in hospitality: graduate career success and strategies. International Journal Of Contemporary Hospitality Management, 20(7), 781-791. https://doi.org/10.1108/09596110810897600

Seetha, N. (2014). Are Soft skills Important in the Workplace? â A Preliminary Investigation in Malaysia. International Journal Of Academic Research In Business And Social Sciences, 4(3), 44 - 53. https://doi.org/10.6007/ijarbss/v4-i4/751

Shafie, H., Syed Khuzzan, S., \& Mohyin, N. (2014). Soft Skills Competencies of Quantity Surveying Graduates in Malaysia: Employers' Views and Expectations. International Journal Of Built Environment And Sustainability, 1(1). https://doi.org/10.11113/ijbes.v1.n1.3

Syafii, W., \& Yasin, R. (2013). Problem Solving Skills and Learning Achievements through Problem-Based Module in teaching and learning Biology in High School. Asian Social Science, 9(12). https://doi.org/10.5539/ass.v9n12p220

Tafti, M., Mahmoudsalehi, M., \& Amiri, M. (2017). Critical success factors, challenges and obstacles in talent management. Industrial And Commercial Training, 49(1), 15-21. https://doi.org/10.1108/ict-05-2016-0036

TalentCorp Malaysia. (2016). Critical Occupation List: Addressing Malaysia's Talent Shortage (p. 1). Kuala Lumpur: TalentCorp. Retrieved from https://www.talentcorp.com.my/clients/TalentCorp_2016_7A6571AE-D9D0-4175-B35D-99 EC514F2D24/contentms/img/publication/MSJ16050704.pdf

Taylor, S. (2017). Forming Character in Business School Leadership Education: Rejoinder to "The Development of Leader Character Through Crucible Moments". Journal Of Management Education, 42(2), 301-305. https://doi.org/10.1177/1052562917742928

Tharenou, P., Donohue, R., \& Cooper, B. (2007). Management research methods. Cambridge [England]: Cambridge University Press.

Thern, E., de Munter, J., Hemmingsson, T., \& Rasmussen, F. (2017). Long-term effects of youth unemployment on mental health: does an economic crisis make a difference?. Journal Of Epidemiology And Community Health, 71(4), 344-349. https://doi.org/10.1136/jech-2016-208012

Tiraieyari, N., \& Abdul Hamid, J. (2015). Is Employability Orientation More Enhanced by Career self- Efficacy or Leadership Attribute?. Modern Applied Science, 9(8). https://doi.org/10.5539/mas.v9n8p57

Towers-Clark, J. (2015). Undergraduate accounting students: prepared for the workplace?. Journal Of International Education In Business, 8(1), 37-48. https://doi.org/10.1108/jieb-11-2013-0043

Van Buren, H. (2003). Boundaryless Careers and Employability Obligations. Business Ethics Quarterly, 13(02), 131-149. https://doi.org/10.5840/beq20031329

Wang, Y., \& Chiew, V. (2010). On the cognitive process of human problem solving. Cognitive 


\section{Macrothink}

International Journal of Human Resource Studies

ISSN 2162-3058 2018, Vol. 8, No. 4

Systems Research, 11(1), 81-92. https://doi.org/10.1016/j.cogsys.2008.08.003

Weber, M., Crawford, A., Lee, J., \& Dennison, D. (2017). CFA and soft skill competencies for entry-level managers. Anatolia, 28(3), 453-455. https://doi.org/10.1080/13032917.2017.1327873

Wittekind, A., Raeder, S., \& Grote, G. (2009). A longitudinal study of determinants of perceived employability. Journal Of Organizational Behavior, 31(4), 566-586. https://doi.org/10.1002/job.646

\section{Copyright Disclaimer}

Copyright for this article is retained by the author(s), with first publication rights granted to the journal.

This is an open-access article distributed under the terms and conditions of the Creative Commons Attribution license (http://creativecommons.org/licenses/by/4.0/). 